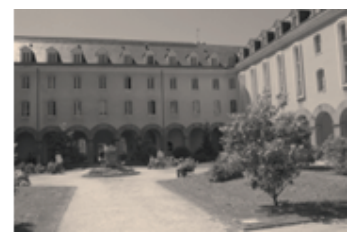

\title{
ON the Political Economics of Tax Reforms: SURVEY AND EMPIRICAL ASSESSMENT
}

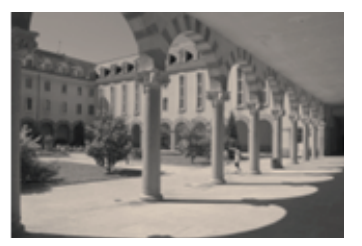

Micael Castanheira

ECARES, Université Libre de Bruxelles, Belgium

Gaëtan Nicodème

European Commission, CESifo, CEPR and Université Libre de

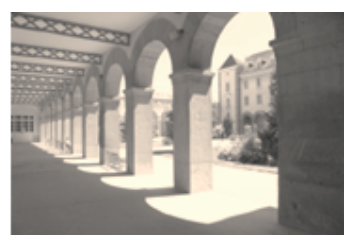

Bruxelles, Belgium

Paola Profeta

Università Bocconi, Econpubblica and Dondena, Italy, CESifo

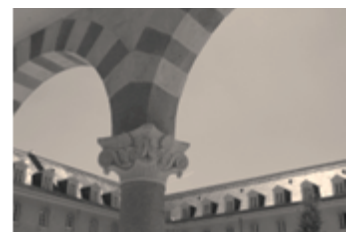

CONDORCET CENTER FOR POLITICAL ECONOMY UNIVERSITY OF RENNES 1 - CREM-CNRS 


\title{
On the Political Economics of Tax Reforms: survey and empirical assessment
}

$1^{\text {st }}$ March 2012

\author{
Micael Castanheira* \\ (ECARES, Université Libre de Bruxelles, Belgium) \\ Gaëtan Nicodème \\ (European Commission, CESifo, CEPR and Université Libre de Bruxelles, Belgium) \\ Paola Profeta \\ (Università Bocconi, Econpubblica and Dondena, Italy, CESifo)
}

\begin{abstract}
Political constraints and incentives are the true driver of tax reforms. This paper reviews the political economics literature on personal income tax systems and reforms to see how political mechanisms help explain tax reforms. We take some of the implications of these theories to the data using LABREF, a database that identifies labor tax reforms in the European Union for the period 2000-2007, and control for economic and labor market factors. We find that political variables carry more weight than economic variables, and we show empirical regularities that support political economy theories. We also find that governments tended to reform more in better economic times, engaging in pro-cyclical behavior.
\end{abstract}

Keywords: political economy, taxation, personal income tax, LABREF.

JEL classification: H11, H21, H24, P16

The authors thank Jean-Pierre De Laet, Benjamin Rausch, Laurent Bouton, participants to the Political Economy Discussion Group at Harvard University and to the 2011 IIPF congress for valuable comments. The findings, interpretations, and conclusions expressed in this paper, as well as possible errors and omissions, are entirely those of the authors. They should not be attributed to their institutions.

*Corresponding author: mcasta@ulb.ac.be. Micael Castanheira has received funding from the European Union's Seventh Framework Programme (FP7/2009-2013) under Grant Agreement n²44725. 


\section{Introduction}

Political constraints and incentives are the true driver of tax reforms. This may explain why there is often a gap between the efficiency and fairness prescriptions based on standard economic theory and actual tax systems. This paper reviews the political economics literature on tax systems and reforms to see how political mechanisms allow us to better understand the drivers of tax reforms. Throughout, our main focus is on the personal income tax (PIT). We then confront the predictions of the literature with observations and present econometric evidence that political economic forces are a strong predictor of tax reforms. Based on these theories and on available evidence, we draw some conclusions on politically-sustainable tax systems and on the feasibility of reform.

A fact is that policymaking is not the deed of an abstract social planner. In democratic societies, policies are made by political parties who must win elections. Thus, political incentives are likely to play a role in shaping tax systems. In sections 2 and 3, we survey the literature that highlight how pre-electoral political incentives shape tax and redistribution systems in the long-run. ${ }^{1}$ We start from the "median-voter" approach and its predictions, and show that they are not borne out by facts. We then move to the probabilistic voting models, which shed light on the incentive of parties to offer lower tax rates to the groups that are electorally mobile. More intense political competition, under some conditions, induces parties to give up more efficiency in order to achieve better targetability. Finally, we analyze the emergence of a trade-off between efficiency and targetability in models based on the Colonel Blotto game. In section 4, we turn to the short run incentives for tax reforms. That is, the process of change from an existing system to another. A status quo bias emerges in tax reforms: improving a tax system means starting from an existing situation and convincing politicians and voters to support a reform of the system. This process creates uncertainty and oppositions. Yet, the government can tailor its reform strategy to try and circumvent this opposition. One strategy is to pursue gradual reforms, which amounts to splitting the reform in different chunks, for instance to target different groups at different moments in time. Finally, information asymmetries between the political elite and the electorate may imply that a given reform proposal can be opposed by the population if it emanates from a party who is felt to be biased in favor of the reform. In that case, parties with positions closer to the median voter (typically centrist parties) may face less opposition than other parties (be them left or right-wing). However, we do not draw normative conclusions on whether actual reforms are too many or too few.

To test such predictions, section 6 exploits a recent database on labor tax reforms in the EU27 for the years 2000-2007, LABREF. We check which political or economic conditions increase the

\footnotetext{
${ }^{1}$ For a survey of the normative side of the literature, i.e. optimal taxation, see Castanheira et al. (2011). For contributions related to the political economy of optimal taxation, see Acemoglu, Golosov and Tsyvinski (2010, 2011) and the empirical analysis of Gruber and Saez (2002).
} 
probability of observing a reform of the tax or social security system. Surprisingly, political variables appear to have more explanatory power than economic factors. High unemployment or a more negative output gap - for instance - are not conducive to more reforms. To the contrary: if anything, a more negative output gap tends to stall reforms.

In contrast, political variables do have a systematic impact on the probability to reform. For instance, coalition governments appear to reform more the broader the coalition. To take one example, we find that ceteris paribus, one additional party in the government coalition increases the likelihood of reform by approximately 10 percentage points. This effect is reinforced when one party dominates the coalition in terms of parliamentary seats. Conversely, a reform appears to be hindered when opposition is less concentrated. This typically happens when different population groups are represented by different parties, in which case opposition is better able at blocking reforms. Importantly, the timing of these reforms appears immune to the political business electoral cycle: reforms are as likely to happen in the beginning or at the end of the parliament's term of office. We also find evidence of reform gradualism: managing to pass a targeted reform in year $t$ increases the probability to pass another reform in year $t+1$. Therefore, a policy conclusion is that to actually produce tax reforms, political constraints and incentives thus need to be put at the centre of economic recommendations.

\section{A Taxing Median Voter}

Since the celebrated works of Downs (1957), a usual suspect of political economics is the median voter. According to the Downs-Hotelling model of political competition, political parties get driven to propose the policies that are preferred by the median voter. When that holds true, explaining the reforms that shape the tax system and the aggregate tax level amounts to understanding the economic preferences of that median voter. A recurrent question is whether and when the median voter theorem holds. Central to the analysis is the assumption that one can actually identify the median preference in the set of policies. ${ }^{2}$ This requires that the policy can be summarized by a point on a line, which could for instance represent the "aggregate" tax rate, or the size of government in the economy. As discussed in the next section, this can be a major limitation. The first generation of research on the political economics of taxation assumes that it does and derives a set of predictions that can be tested against data. Here, we detail the main set of theoretical predictions and how they were empirically tested. We shall see that several predictions fail to pass the empirical test.

The median voter approach to taxation and redistribution was pioneered by Romer (1975), Roberts (1977) and Meltzer and Richard (1981, 1983). They consider a setup with one marginal tax rate (hence a single dimension) $\tau$. The value of $\tau$ is determined through a direct vote. This ensures that

\footnotetext{
${ }^{2}$ See Persson and Tabellini (2000, ch.p 2) for a review of some sufficiency conditions.
} 
outcomes are not biased by the incentives of politicians or by information asymmetries. For the sake of the illustration, consider the case in which the electorate must set both an initial tax level (be it positive or negative) $\tau_{0}$ and a marginal rate $\tau$, such that an individual $i$ with taxable income $T I(i)$ ends up paying a total Personal Income Taxes (PIT):

$$
\operatorname{PIT}(i)=\tau_{0}+\tau \times T I(i) .
$$

Romer (1975) and Roberts (1977) show that majority voting need not lead to a progressive tax schedule (i.e. a negative value for $\tau_{0}$ and a large marginal tax rate $\tau$ ). Actually, if a majority of the population has sufficiently high skills, the tax rate chosen by the median voter "will be lower than the tax rate we would pick were we using a Rawlsian maxi-min criterion" (Romer 1975, p176). She may even choose a regressive tax schedule (i.e. $\tau_{0}>0$ and a lower level of the marginal rate $\tau$ ).

Meltzer and Richard (1981) provide a rational theory of the size of government. They assume that tax revenues are redistributed uniformly across the population. The amount redistributed to any citizen is then $b=\tau T I_{\text {avg }}$, where $T I_{\text {avg }}$ denotes the average of all taxable incomes. From an efficiency standpoint, the optimal tax rate is thus zero. Yet, an individual $i$ receives a positive net transfer whenever her income is below the average. Hence, she supports strictly positive tax rates. Absent tax distortions, all such voters would actually vote for a $100 \%$ rate, whereas the voters above the average would vote for a zero tax rate. Factoring in the distortionary costs of taxation yields that the poorer the voter, the higher her preferred tax rate. Only voters close or above the average income prefer the efficiency-maximizing tax rate, zero. Meltzer and Richard (1981) thus conclude that the more unequal the income distribution among the voters, the higher the tax rate (and the size of government).

Meltzer and Richard (1983) empirically tested, and apparently validated, their model based on the evolution of government size over the period 1938 to 1976 in the U.S. Their main explanatory variable is $\mathrm{TI}_{\text {median }} / \mathrm{TI}_{\text {avg }}$, which is the ratio of the income of the median earner to that of the average earner, a summary for inequality. Yet, as Mueller (2003, pp. 518-519) emphasizes, this contrasts with the finding of Tullock (1983), who "pointed out [that] this ratio has been virtually constant since World War II, yet it 'explains' a significant fraction of the growth of government. Meltzer and Richard's test essentially amounts to regressing one long-run trend variable on another. Any other long-run trend variable might yield a similarly high correlation". However, Scheve and Stasavage (2010) shows that mobilization for mass warfare (esp. WWII) led to increasing demand for progressive tax systems in order to distribute the burden for the war effort more fairly, as the young and less wealthy were more likely to be enrolled.

The real test is thus to confront this theory to a panel of data that allows comparisons both over time and across countries. In this case, the model generally fails the test, as the effect of income inequality is often insignificant or takes the wrong sign (see e.g. Perotti 1993 and 1996, Bénabou 1996, Gouveia and Masia 1998, Bassett et al. 1999, Borck 2007). However, such tests do not look at actual redistribution patterns; they only focus on the size of government. In reality, redistribution 
patterns can be very complex. A large state and high taxes may generate little redistribution across income quantiles (see e.g. Le Grand 1982 or Esping-Andersen 1990).

A more direct way to look at the redistributive effects of tax systems is thus to compare factor and disposable incomes for different quantiles of the earning distribution. This has recently become possible thanks to the Luxembourg Income Study (LIS). Milanovic (2000) computes the share gain for each of the bottom five deciles (in the factor income distribution). These gains are defined as "the difference between the share of a given decile in factor and disposable income. For example, if the bottom decile receives $2 \%$ of total factor income, while the same people receive $8 \%$ of total disposable income, the share gain is 6 percentage points." (p. 375). He demonstrates that a significant fraction of redistribution takes place through pensions. ${ }^{3}$ When pensions are not considered, a reduction of 1 percentage point in factor income is on average matched by (a) an increase in redistribution of about 0.7 percentage point for the citizens with an income below the median, and (b) an increase in redistribution of about 0.93 percentage point when only the bottom quintile is considered. In other words, if the very poor lose one percentage point in factor income, their loss is almost fully compensated by an increase in transfers. This difference runs against the median voter hypothesis. Further, Milanovic (2000) shows that the median typically loses from these transfers: the $5^{\text {th }}$ and $6^{\text {th }}$ deciles respectively lose $3.6 \%$ and $10 \%$ on average. Borck (2007, section 4 ) surveys other empirical evidence and also shows that the evidence is broadly against the Meltzer-Richard hypothesis.

In conclusion, (1) theory shows that the median voter herself may develop an incentive to increase tax rates above efficient levels. All inefficiencies in actual tax systems can thus not be blamed on failures in the political process as there can be an inherent demand for excess taxation in the population; and, (2) empirically, some comparative statics on tax levels are found to go in a direction opposite to this median voter type of predictions. One should thus refrain from focusing on a pure "median voter" approach to study the forces actually shaping tax reforms.

\section{Voting on complex tax schemes}

As said above, a reason for the apparent failure of the median voter approach to taxation is that the voting problem must be modeled as single-dimensional, requiring that the tax rate is uniform. Actual tax systems are instead non-linear and transfers not uniform, which makes the problem fundamentally multidimensional. Moreover, extending the median voter approach to multiple dimensions fails to produce a stable equilibrium. ${ }^{4}$ This failure stems from the combination of two factors: (1) Voter reactivity: each voter compares the policy proposed by each party, and votes for the

\footnotetext{
${ }^{3}$ This partly biases the results: a rich individual who retires and benefits from a generous public pension will be perceived as receiving a large transfer. We thus focus on the results that leave pensions out.

${ }^{4}$ Several authors worked on narrowing down the set of policies that could be proposed in a mixed strategy equilibrium (see for instance Davis, De Groot and Hinich 1972, Schofield 1983, and Laver and Shepsle 1996).
} 
proposal that maximizes her utility, and (2) Full targetability: parties can perfectly and separately target each dimension of the policy.

To illustrate this instability of the multidimensional median voter equilibrium, imagine three equally-sized groups in the population: $A, B$ and $C$. Policy is bi-dimensional because (a) each party can offer a different tax level to each group but (b) the government budget constraint imposes that $\tau_{\mathrm{A}}+\tau_{\mathrm{B}}+\tau_{\mathrm{C}}=G$, where $G$ is the level of government spending. Thus, the tax level imposed on $C$ directly follows from the tax levels on $A$ and $B$. The budget constraint removes one degree of freedom: a proposal only has two independent dimensions. Now imagine that a party makes an equalitarian proposal: $\tau_{\mathrm{A}}=\tau_{\mathrm{B}}=\tau_{\mathrm{C}}=G / 3$. The other party wins the election with two thirds of the votes as soon as it reduces the tax level on any two groups and, consequently, increases the tax level on the third group. This implies that no party wants to make an equalitarian proposal. Further, for any tax offer by one party, the other party can always regain a two-third majority by cutting the tax level of any two groups, and increasing it for the third group. Repeating this argument from one party to the other, one finds that no proposal can be a "pure strategy" equilibrium. In other words, the median voter approach fails as soon as the factors (1) and (2) above are combined. To go beyond this limitation, we thus need approaches to tackle more complex tax schemes: probabilistic voting models and Colonel Blotto games.

\subsection{Probabilistic voting models: lower taxes for swing voters}

In the above approach, cutting down the tax by any minimal level is sufficient to attract all the votes from any group of voters. The probabilistic voting model instead reckons that voters do not only look at policy proposals. They also consider other factors which, for tractability, are compressed into a random term, meant to capture dimensions such as charisma, political mood, etc. that are elusive and that the modeler cannot capture precisely. The implication of this random term is that, given any two pair of policy proposals, both the modeler and the political parties can only compute the probabilities that a given (group of) voter(s) cast a ballot in favor of either platform (Lindbeck and Weibull 1987, Dixit and Londregan 1998). In that case, a small tax cut only increases the probability that the group votes for you by a small amount. While such a modification may seem trivial, it has an important technical consequence: the expected number of votes received by either party becomes a smooth function of the proposed tax rates. This contrasts with the classical median voter approach, in which a minimal change in policy can lead to a discontinuous jump in vote support. With continuous voting responses, the probabilistic voting approach can tackle complex tax systems and often features a unique solution in probabilistic voting models (see Lindbeck and Weibull 1987 for conditions of equilibrium existence). 
The typical equilibrium features the two parties proposing the same platform. ${ }^{5}$ This platform balances the opposing interests present in the electorate, and takes into account the political influence of each group. The tax structure that emerges is quite realistic, with those groups who are most mobile across parties being also the most favored by the tax system (see Warksett, Winer and Hettich 1998, Winer 2001, Galli and Profeta 2009, Profeta 2008). In a nutshell, equilibrium net tax rates $^{6}$ are not inversely proportional to the elasticity of income with respect to the tax rate as advocated by the Ramsey (1927) rule. They are rather influenced by the between-party electoral elasticity of each voting group. Electorally mobile (i.e. swing) voters pay lower taxes in equilibrium. The equilibrium mimics the efficient Ramsey rule only when the distribution of the random term (that represents the political appeal of each party) is identical across all groups of voters. When this distribution is not identical -the most likely case- candidates compete more aggressively for the voters that have the highest "electoral elasticity": swing voters being ideologically more neutral, they are more easily attracted by a given tax favor than steadfast party supporters. ${ }^{7}$ In the political equilibrium, politically mobile groups thus benefit from lower effective taxes (for a more formal review of the model, see Castanheira, Nicodème and Profeta, 2010, and see Profeta 2007 for an application to Italy).

As pointed out by Lindbeck and Weibull (1987), if those 'mobile' voters are the middle class, which is likely in a two-party system, then the structure of tax and public good provision will reproduce what Stigler (1970) termed Director's Law, after Aaron Director. In an "ends against the middle" equilibrium, the rich and the poor pay relatively high taxes and receive little public goods in return, while the middle class benefits the most. Yet, Feld and Schnellenbach (2007) observe that the bulk of the redistribution towards the middle takes place through transfers, rather than through the tax system.

This probabilistic voting framework also helps explain how policymakers introduce their tax reforms: a candidate interested in winning the election will prefer to sacrifice some economic efficiency and introduce distortions that favor politically mobile voters. Comparative statics also suggest that (i) proposed policies will be more alluring to the voter groups that are larger in size (number of voters); and (ii) both left- and right-wing parties should propose similar tax reforms, since they face the same set of incentive conditions. Our empirical analysis below partly confirms this: many tax reforms have been similar under both left- and right-wing governments.

\footnotetext{
${ }^{5}$ See also Calvert (1985), Wittman (1983) and Roemer (2001) for models in which the politicians' ideology prevents platform convergence.

6 'Net' means the difference between the taxes paid and the subsidies received.

${ }^{7}$ Interestingly, this means that the entry of a new party, say on the right-end side of the political spectrum, should induce the other parties to propose lower taxes for the rich than before the entry of this new party.
} 


\subsection{Colonel Blotto games: the efficiency-targetability trade-off}

The "Colonel Blotto game" approach was pioneered by Myerson (1993). It builds on a mathematical representation of how a colonel should allocate his troops across battlefields: scattering troops makes him moderately weak on all battlefields. Focusing troops on fewer battlefields increases the chance of victory there, but also ensures that the enemy has an easy win in the other battlefields. In equilibrium, the best strategy is one of surprise: Colonel Blotto must randomize the number of troops in each battlefield, to prevent the opponent from anticipating where he should allocate his own troops.

Myerson's (1993) extension of Colonel Blotto games adapts this reasoning to the allocation of budget and taxes across voter groups. The upshot will be similar to the military application of this game: each political party should randomize tax cuts or spending hikes across groups. In practice, this amounts to abandoning the assumption of full targetability: let us go back to the above example. If a party offers the tax schedule $\tau_{\mathrm{A}}=\tau_{\mathrm{B}}=\tau_{\mathrm{C}}=G / 3$, the other party should propose to reduce taxation for two groups. But to pre-empt the possibility of retaliation by the first party, it should not target two groups in particular. It should randomize. Which group prefers either party will thus only be learnt at the time of the election. With this approach, the modeler loses the ability to predict which group receives which offer but it can identify which tax schedules emerge given the institutional system and the intensity of political competition. ${ }^{8}$

A striking result is that politicians will always make unequal offers. Indeed, imagine that there are two politicians and the government budget is normalized to 1. Imagine that the first politician proposes a fully equalitarian offer. That is, she splits the budget equally across all voters. The second politician can then offer 0 to a fraction $x$ of the population, and increase the transfer to $1 /(1-x)$ to the remaining fraction of the population, with size $(1-x)$. These prefer the offer of the second politician. For $x \rightarrow 0$, almost all the population prefers the second politician: deviating from the equalitarian offer would provide an overwhelming majority to politician 2. Politician 1 can thus not make the equalitarian offer if she wants to have a chance of winning the election.

The degree of inequality will tend to increase with political competition: the more candidates (or party niches), the more targeting is needed to win a seat. For instance, with ten candidates, each candidate has an incentive to be extremely generous to a bit more than a tenth of the population to win a plurality of votes. With 20 candidates, one should concentrate resources on a twentieth of the population, and so on. In a first-past-the-post system, distortions are thus minimized when only two candidates are competing for election. By extension, in a proportional representation system, the

\footnotetext{
${ }^{8}$ The typical equilibrium of such a game can only be represented by a Lorenz curve, which identifies how many percents $p(x)$ of the population pays less taxes (or benefits from larger transfers) than some level $x$ and how many percents $1-p(x)$ receives less (or pays more) than $x$. See Myerson (1993), Lizzeri and Persico (2001, 2005) and Crutzen and Sahuguet (2009) for more detail.
} 
number of distortions should be increasing in the number of niche parties. Other systems can produce more or less inequality.

Lizzeri and Persico $(2001,2005)$ extend the model by letting politicians choose between a general public good, which has a high social value, and redistributing money, which has no social value. They show that proportional representation systems will be more efficient at producing the public good, and that increasing political competition (by increasing the number of candidates) will increase social waste in equilibrium. Crutzen and Sahuguet (2009) provide the first formalization of the political economic determinants of a tax system based on this type of games. They begin with a simple case with no public good: with this normalization, there should be no tax, to avoid economic distortions. The political incentives underlined above induce politicians to nevertheless levy a tax, in order to finance (inefficient) transfers. The efficiency loss is shown to be hump-shaped in distortions: if distortionary effects are extremely large, high taxes would lose many votes, and only win a few. Thus, equilibrium taxes are low, which maintains distortions at a low level as well. With intermediate distortionary effects, equilibrium taxes will be high, and so will be distortions. Finally, with minimal distortionary effects, equilibrium taxes will be maximal, but distortions will be small again. They also show that politicians will always use targetable taxes in equilibrium, possibly in conjunction with nontargetable taxes to increase the amount of transfers.

Focusing on Belgium, Castanheira and Valenduc (2006) study a number of tax exemptions that are best explained by the government's incentive to target resources on narrow groups, to ensure higher winning probabilities in these "battlefields". They identify for example the case of the special tax exemptions granted to small and medium enterprises. An economic rationale for such exemptions could be to promote economic activity and address liquidity problems. Yet, in practice, such efficiency arguments rarely apply. In the case of Belgium, the Conseil Supérieur des Finances, a supervisory body, did point at the additional inefficiencies and distortions introduced by these exemptions. Among others, they induce some entrepreneurs and independent workers to incorporate for tax avoidance reasons (see e.g. de Mooij and Nicodème 2008), and create the perverse incentive to lower enterprise growth. In contrast, the political economy rationale is that the government coalitions observed across the years made SMEs a key political player, regularly allured by political parties.

\section{Reforms: how broad and how fast?}

While the previous section describes the type of tax and redistribution systems that preelectoral political interactions should produce in the long-run, this section discusses the process of change from an existing system to another. ${ }^{9}$ The idea is the following: consider a politician who,

\footnotetext{
${ }^{9}$ For a more in-depth discussion of these processes, see Castanheira, Nicodème and Profeta (2010) who accompany their review of the economic literature with an illustration of the political economy of flat tax reform in Estonia.
} 
having been elected, wants to engineer an efficiency-enhancing reform. Reforms differently affect the welfare of each group or individual: some groups will be hurt and may oppose reform. This is why an efficiency-enhancing reform based on sound economic theory may face steadfast political opposition. The question is how the reform-minded policymaker can jump such political hurdles. We will see that coalition building may require sacrificing some efficiency in the reform: oddly enough, economically inferior reforms may be more palatable politically. A second question is whether a politician actually has the incentive to press for efficiency-enhancing reforms. We will review the argument that crises can be necessary to trigger reform as they may increase the support for reform. Finally, while most of the literature focuses on the reform process itself, we also wish to relate it to the reasons why the status quo emerged in the first place.

\subsection{The status quo bias}

To explain why governments may fail to adopt policies that are considered efficiencyenhancing, Fernandez and Rodrik (1991) focus on the role of individual uncertainty generated by reforms: while the losers from a reform are easily identifiable, the gainers are more uncertain. A numerical example helps to illustrate this point. Consider a population divided in two sectors: $L$ is the sector (or group) that stands to lose from the reform. $G$ is the sector that stands to gain. Ex-ante, $54 \%$ of the population works in sector $L$. Thus, a majority of the population potentially stands to lose. Yet, the productivity gains in sector $G$ imply that this sector will grow. Imagine that ex post, $64 \%$ of the population will be working in sector $G$. Therefore, a majority of the population (64\%) will actually gain from the reform: those who are already present in sector $G$ ( $46 \%$ of the population), and the additional $18 \%$ who will move from one sector to the other (see Figure 1).

The issue is that each single individual in sector $L$ is uncertain about who in $L$ will move to $G$. Assume that the reform increases the payoff of anyone in sector $G$ by 10 , while decreasing the payoffs of anyone in sector $L$ by 8 . Thus, with probability $2 / 3,{ }^{10}$ an individual initially in sector $L$ loses 8 and, with probability $1 / 3$, he or she gains 10 . This implies that, from an ex ante standpoint, all $L$-sector workers are opposed to the reform, since they face a negative expected pay-off of -2 . This ex ante constraint means that the reform is blocked by a majority: even a well-meaning politician faces the impossibility to pass the reform. Note the irony: after the reform is implemented, a majority of the population would actually be in sector $G$ and support the reform (or oppose its reversal).

One may also imagine another reform, which would attract majority support ex ante, e.g. by giving strong compensation to those who remain in sector $L$, but which is rejected ex post, e.g. because the compensations are so high that the ones now in sector $G$ prefer the initial situation. Summing up, this political economy approach to reforms shows that proposed reforms must overcome the status quo

\footnotetext{
${ }^{10}$ Calculated as $(54-18) / 54$
} 
bias, that is, obtain support from a majority both ex ante and ex post. ${ }^{11}$ By contrast, a purely economic approach would focus on aggregate gains. ${ }^{12}$

\begin{tabular}{|c|c|c|}
\hline Prior to reform & & After reform \\
\hline \multirow{2}{*}{ 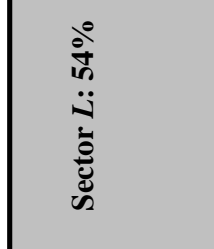 } & $\begin{array}{l}36 \% \text { would eventually } \\
\text { lose from reform }\end{array}$ & 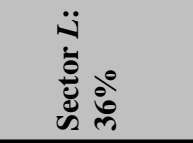 \\
\hline & $\begin{array}{l}18 \% \text { would change sector } \\
\text { and gain from reform }\end{array}$ & \multirow{2}{*}{ 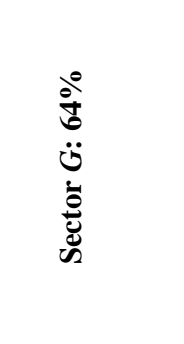 } \\
\hline 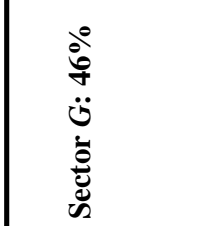 & $\begin{array}{l}46 \% \text { remain in sector } G \\
\text { and gain from reform }\end{array}$ & \\
\hline
\end{tabular}

Figure (1): Gainers and losers from reform

\subsection{Bundling and speed of reform}

Political support and opposition also depend on how reforms are bundled and sequenced. Given the intrinsic uncertainty of reforms, it may be optimal to delay some reforms, until uncertainty gets resolved; e.g. a country $B$ waits to see the performance of a similar reform in country $A$. In this case, $B$ 's reforms are expected to be implemented late, but quickly. Conversely, country A may benefit from introducing reforms gradually, e.g. by testing the reform on specific sectors, to benefit from an experimentation phase. In Dewatripont and Roland (1995) for instance, a major reform is split into two smaller reforms and each of them is introduced at a different time. Typically, the first reform should be the one with the highest expected payoff and the highest probability to reveal information about the entire process. This gradualism helps winning out some of the ex-ante opposition in support of the second reform: whenever the first reform produces benefits above expectation, some of the opposition transforms into support for more reform.

Splitting reforms in bits can also help overcome the status quo bias, by dividing opposition and obtaining a different majority at each stage of the reform. These are called divide-and-rule tactics (see Dewatripont and Roland 1992 for a detailed analysis). The efficiency of gradualism may however be weakened when many groups have veto power on the reform (Martinelli and Tommasi 1997), and war-of-attrition between the different groups who may win or lose from the reform may produce

${ }^{11}$ See Roland (2000) for an in-depth analysis that focuses on transition countries and Valenduc (2006) for an application to Belgium.

${ }^{12}$ Note that efficiency gains are a necessary, but not sufficient, condition to satisfying both the ex ante and the ex post constraint. 
inefficiently long delays, followed by big bang reforms (Alesina and Drazen 1991, Drazen 1996). ${ }^{13}$ According to these theories, one should thus either observe one substantial and comprehensive reform or a set of gradual and targeted reforms that follow one another (see also Boeri et al. 2006 for a more detailed overview of the strategies available to the reform-minded government). When the latter strategy is implemented, the successful passing of a reform should increase the likelihood of subsequent reforms.

\section{Information asymmetries and policymaker incentives}

The above analysis focuses on the cases in which voters and politicians have access to the same information. In reality, voters should be "rationally ignorant" (Downs, 1957): collecting information about each policy is very costly for a voter who has virtually no chance of affecting the election outcome. This gives policymakers room for manipulation of economic policies. To increase their chances of being re-elected, policymakers may for instance have the incentive of engineering a political business cycle (Nordhaus 1975, Rogoff and Sibert 1988, Alesina 1987 and 1988): the incumbent takes measures to boost employment (possibly at the expense of higher inflation) before the election, and tightens up policy right after the election. Such an incentive may translate into manipulating tax systems: the incumbent may be tempted to implement tax reforms that please voters in the year before the election and, when they lean against voter prejudice, to focus the more difficult reforms just after the election.

It sometimes takes a bold policy reform in one country to revert popular perceptions in the other countries. This is a well-known issue in yardstick tax competition: when voters can compare their government's tax policies with those of neighboring jurisdictions, they may induce taxmimicking behaviors on the part of their own government (Besley and Case, 1995a). There is an ample literature showing these effects (e.g. Besley and Case, 1995b; Heyndels and Vuchelen, 1998; Revelli, 2002; Bordignon, Revelli and Cerniglia, 2003; Edmark and Agren, 2007). One result of these studies is that, because of such informational spillovers, the prospect of facing an election soon can actually trigger efficiency-enhancing tax reforms, thereby reverting the political-business cycle hypothesis.

Informational concerns can also prevent the reform-minded policy-maker from implementing efficiency-enhancing reforms. As argued by Cukierman and Tommasi (1998) if people expect proreform governments to push for reforms in any case, they will be more reluctant to believe the policymaker's claim that a reform is necessary. As a result, the pro-reform government will implement fewer

\footnotetext{
${ }^{13}$ Rodrik (1996) challenges the latter theory on the ground that it is "unfalsifiable": if a reform takes place, it is normally meant to address some problem but is it necessarily a "crisis"? Alternatively, if no reform takes places, would it mean that the crisis was not serious enough?
} 
reforms than a policy-maker perceived as more neutral, because voters would trust her word more easily.

\section{The political economics of tax reforms: an empirical test}

In this section, we bring testable implications of the theories reviewed in sections 3 to 5 to the data, and explore the role of political factors as determinants of tax reforms in Europe using the $L A B R E F$ database, managed by the European Commission. Among other information, this database registers the legislative reforms of the personal income tax and of the social security regime passed by the governments of the European Union Member States. Compared with previous studies, the valueadded of this database is to offer a unique opportunity of assessing the actual timing of the governments' decisions to assess which forces shape these decisions. In contrast, the literature typically looks at economic aggregates such as the share of taxes and government spending in GDP. These measures have the advantage of being more encompassing, but are at least as much influenced by economic shocks as by government choices.

Equipped with this data, we can identify a number of clear comparative statics from the set of theories surveyed above, and that can be tested with such reform data. Obviously, our empirical exercise cannot exhaust all testable implications, nor identify the weight of each theory in explaining the observed patterns. Still, we will see that a surprisingly large number of the following predictions are borne by the facts:

- A central prediction of both the probabilistic voting and Colonel Blotto theories (Section 3) is that most reforms should be targeted. While we cannot predict which groups should be targeted, we can check whether these targeted reforms can be explained by political factors surveyed above, or by economic factors that may rest on other (efficiency and/or redistribution) arguments.

- In particular, Colonel Blotto Games (Myerson 1993, Lizzeri and Persico, 2001 and 2005) suggest that a higher number of political parties should increase the number of target groups, and therefore the number of reforms. This result may depend on the respective power of each political party.

- Reforms may depend on the length of the legislature (see also Schultz, 2008). For instance, longer tenure reduces electoral competition and therefore the incentive for electorally-motivated reform.

- Policymakers may need to develop gradual reforms and introduce a sequence of targeted reforms to circumvent the status quo bias (Section 4, in particular Dewatripont and Roland, 1992, 1995).

- According to the political business cycle literature, tax reforms should be timed with the electoral cycle (see section 5).

- According to the war-of-attrition theory, governments should reform more in times of crisis (Section 4, in particular Alesina and Drazen 1991).

- Reforms may be easier with governments that are less biased towards reform (Section 5, in particular Cukierman and Tommasi 1998). 


\subsection{The data}

In this section, we investigate the empirical determinants of tax reforms and assess some of the theories. The LABREF database includes all current 27 Member States for years between 2000 and 2007. ${ }^{14}$ Within this dataset, we focus on three sets of tax reforms: changes in personal income taxation (PIT), changes in social security contributions of employees (SSCe) and changes in social security contributions of employers ( $\mathrm{SSCr}$ ). The rationale for focusing on labor taxation instead of other taxes, such as indirect and corporate taxation, is to isolate those reforms that are most visible and concern voters most directly. ${ }^{15}$

Table (1): Reforms of labor income taxation in the European Union

\begin{tabular}{lcc}
\hline Reforms & Total number & $\begin{array}{c}\text { Of which, at least one reform } \\
\text { is targeted }\end{array}$ \\
\hline PIT, SSCe, SSCr & 9 & 7 \\
PIT, SSCe & 5 & 5 \\
PIT, SSCr & 15 & 10 \\
SSCe, SSCr & 6 & 0 \\
PIT only & 57 & 31 \\
SSCe only & 3 & 3 \\
SSCr only & 22 & 15 \\
Total & $\mathbf{1 1 7}$ & $\mathbf{7 7}$ \\
\hline
\end{tabular}

Source: LABREF and own calculations. PIT, SSCe and SSCr represent personal income tax, social security contribution of employees and social security contribution of employers, respectively.

With this database, we identify whether each legislative reform positively or negatively affects the rate and/or the base and whether the reform was targeted to taxpayers with specific characteristics, such as old workers, young workers, self-employed, families with children, high or low-income, etc. In our sample, we identify 86 reforms of personal income taxation (among which 47 were targeted to specific population groups), 23 reforms of social security contributions of employees (among which 15 were targeted) and 53 reforms of social security contribution of employers (among which 33 were targeted). We codify these by creating a variable "reform" that takes value 1 if a reform of one of these three types occurs in a specific country in a specific year and 0 otherwise. In the same vein, we create a variable "targeted" that takes value 1 if a targeted reform of one of these three types occurs in a specific country in a specific year and 0 otherwise. Table (1) provides summary information on the 117 reforms, of which 77 were targeted. ${ }^{16}$

\footnotetext{
${ }^{14}$ Notice that there is no information for reforms in social security contributions in Bulgaria between 2000 and 2002.

${ }^{15}$ Instead, the political economics of indirect and corporate taxes is likely driven by special interest politics (see e.g. Grossman and Helpman 2001).

${ }^{16}$ A question is whether these reforms are meant to increase economic efficiency or primarily to target voting groups. In an ideal world, one would solve for the optimal tax system conditional on the socio-economic and political conditions in each country and check whether a given reform goes in that direction or not. But this is much beyond current feasibility constraints. To proxy for potential efficiency enhancements, we identify a subset
} 
To assess the effects of political factors, we have collected indicators from the Database of Political Institutions, run by the World Bank (see Keefer, 2007). This database provides information on the political framework and the composition of executive and legislative institutions in most countries of the world between 1975 and 2006. To match these data with the data coming from $L A B R E F$, we have updated the database for our countries of interest with 2007 data. Next, we use information contained in the yearly CIA Factbooks between 2000 and 2007, which also provides socio-economic information. Finally, we also use economic data provided by the AMECO and LIME databases run by the European Commission, as well as OECD data on Labor Force Statistics.

\subsection{Estimation technique}

We rely on the use of discrete choice modeling techniques and use the binary logit approach for this purpose. The choice of implementing a reform may be viewed as a variant of McFadden's random utility maximization model (see Long and Freese, 2006). This approach assumes that governments choose whether or not to reform depending on the impact on a latent (i.e. unobservable) variable $y^{*}$ (e.g. the expected political advantage, or gain in efficiency). Additionally, observed political and socio-economic characteristics are assumed to directly influence this latent variable. They enter the profit function of a given government $i$ as follows:

$$
y_{i}^{*}=X_{i} \beta+\varepsilon_{i},
$$

where the latent variable $y^{*}$ of government $i$ depends on observed independent variables represented by $X_{i}$ and a random component $\varepsilon_{i}$. The government actually reforms (the observed decision $y_{i}$ takes value 1) whenever the latent variable exceeds a threshold, normalized to zero:

$$
\begin{aligned}
& y_{i}=1 \text { if } y_{i}{ }_{i}>0 \\
& y_{i}=0 \text { if } y_{i}^{*} \leq 0
\end{aligned}
$$

Table (5) provides summary statistics on the main political variables and controls used in the subsequent empirical work to explain reform decisions. The mean value of reform - a dummy variable capturing the occurrence of a reform - is 0.542 and the mean value of targeted - a dummy variable capturing the occurrence of a targeted reform - is 0.356 . Among the political controls, execoalition is the number of parties present in the governing coalition, which varies in our panel from 1 to 8 (for a grand coalition government in Italy), with a mean value of 2.7. A larger number of coalition partners is expected to increase the number of reforms -albeit not necessarily their efficiency- because it increases the number of population groups targeted by political competition (Lizzeri and Persico, 2005). However, this process may depend on the respective power of each political party and/or on the

of targeted reforms which we call "Lisbon". These are the reforms targeted on older workers, female workers, job seekers or low income taxpayers that decrease either their (tax or social contribution) rate or the base. The 'Lisbon strategy' (now: Europe2020) specifically targets these categories to boost economic growth, employment and social progress in Europe. There are 65 reforms of that type. 
presence of a dominant party in the coalition. To control for this, we include Herfgov, a variable computed as the Herfindahl index of the parliamentary seat share of each government party (the share relates to the total number of seats controlled by government partners). A similar variable, Herfopp, is computed for the opposition. The decision to reform may also depend on the size of the majority of the ruling coalition and we therefore include maj, the proportion of seats of the majority whose mean value in our sample is $54.4 \%$. Next, we add parliamentterm as a variable capturing the length of the legislative mandate ( 4 or 5 years, with an average of 4.3). To capture for electoral business cycle effects, we compute parlyterm, as the ratio of the number of years left in the current mandate over the length of the mandate. As seen in Section 5, Cukierman and Tommasi (1998) show that reforms may be easier with governments that are less biased towards reform. To capture these effects, we consider the variables left and right, two dummy variables capturing the political wing of the ruling coalition, with 0 being a centrist, and Govspec, a dummy variable indicating whether a member of the ruling coalition has special political (nationalist, regional, religious or rural) interest.

Table (2): summary statistics

\begin{tabular}{llllll}
\hline Variable & N\# obs & Mean & Standard dev & Min & Max \\
\hline Reform & 216 & 0.542 & 0.499 & 0 & 1 \\
Targeted & 216 & 0.356 & 0.480 & 0 & 1 \\
Lag reform & 189 & 0.529 & 0.500 & 0 & 1 \\
Lag targeted & 189 & 0.354 & 0.480 & 0 & 1 \\
Execoalition & 216 & 2.708 & 1.341 & 1 & 8 \\
Herfgov & 216 & 0.654 & 0.258 & 0.180 & 1 \\
Herfopp & 216 & 0.506 & 0.200 & 0.213 & 1 \\
Maj & 216 & 0.545 & 0.076 & 0.357 & 0.732 \\
Parlyterm & 216 & 0.405 & 0.284 & 0 & 1 \\
Parliamentterm & 216 & 4.259 & 0.439 & 4 & 5 \\
Left & 216 & 0.361 & 0.481 & 0 & 1 \\
Right & 216 & 0.333 & 0.472 & 0 & 1 \\
Govspec & 216 & 0.194 & 0.397 & 0 & 1 \\
Outputgap & 216 & 0.309 & 2.488 & -7.286 & 13.056 \\
Complgovemp & 216 & 11.075 & 2.509 & 6.844 & 18.025 \\
Lagitrlabor & 211 & 35.344 & 6.812 & 19.1 & 48.5 \\
Pop65 & 216 & 15.187 & 2.055 & 11.0 & 20.0 \\
Ethnic & 216 & 0.824 & 0.175 & 0.415 & 1 \\
Epl & 144 & 2.261 & 0.606 & 1.05 & 3.53 \\
Emplgendergap & 183 & 19.657 & 9.775 & 3.7 & 46 \\
Actrateolder & 189 & 42.285 & 12.064 & 22.6 & 72.8 \\
Uniondensity & 161 & 32.908 & 20.049 & 7.31 & 79.08 \\
\hline
\end{tabular}

Next, we include economic control variables. Outputgap measures the output gap of the economy, with a positive value indicating higher growth than potential. Alesina and Drazen (1991) show that reforms can be more likely during economic crises. If that is the case for tax reforms, we should expect a negative relationship between outputgap and the probability to reform. Complgovemp captures the share of the compensation of labor of government employees in the economy and measures the power of state officials. Finally, lagirtlabor is the lagged value of the implicit tax rate on labor. A high ITR is expected to be an economic incentive to reform and decrease labor taxation. 
Socio-economic factors are captured by four variables: Pop65, is the share of the population aged 65 or more, and Ethnic is the Herfindahl index of the various ethnicities composing society, with a value of 1 indicating a homogeneous population. An ageing population could be an incentive for governments to reform -because of public finance constraints- but can also be an obstacle if this category prefers the status quo. Heterogeneous populations might reflect heterogeneous preferences for reform, and the potential number of niches that parties can exploit. We also consider emplgendergap, the difference of employment rate between male and female workers. Its average is a high $19.7 \%$ and it varies between $3.7 \%$ and $46 \%$. A higher value should act as an incentive to promote female employment. The same logic guides the use of actrateolder, which is the activity rate of older (55-64 y.o.) workers.

Finally, we include labor market variables. The Employment Protection Legislation index, epl, is a measure of labor market flexibility. It varies between 1 and 6 , indicating legislation that is respectively lenient or strict. A labor tax reform may be a complement or a substitute to reforms of labor market legislation. Finally, uniondensity is the degree of labor unionization. The presence of strong trade unions may either facilitate the adoption of some reforms thanks to better social dialogue or strengthen the resistance to change.

\subsection{Empirical results}

Table (3) provides our empirical results from a logistic regression where the endogenous variable is the probability that a reform in labor taxation occurs in a given country and year. Table (4) provides similar regressions for targeted reforms. All regressions include time fixed effects. ${ }^{17}$ In both tables, we start with regression (1) as our base case, which includes political economy variables only. Execoalition, the number of political parties in the ruling coalition enters in regression (1) of Table (3) with a coefficient of 0.450 that is significant at the $1 \%$ level. Alternatively, the marginal effects reported between square brackets indicate that increasing the number of political parties by 1 increases the probability of reform by $11.1 \%$. This result lends support to Lizzeri and Persico's (2005) prediction that stiffer political competition increases the number of niches targeted by political parties. They then introduce more reforms to obtain increased political support (the effect is similar with targeted reforms, see below). Next, Herfgov, the Herfindahl index of governmental parties enters positively and significantly at the $5 \%$ level, indicating that governments with a dominant party are more likely to reform. The observation is consistent with the idea that the dominant party gives direction for reforms and buys out support from each coalition partner with other reforms that they can

${ }^{17}$ In an unreported regression, we jointly used time and country fixed effects. Including these effects does not affect the signs and magnitude of our coefficients but reduces their significance: they pick up a large part of the influence of political systems that we aim to study. Because of this and because of the relatively short timeframe that limits the variance of some variables, we chose not to include them. 
bring to their electorate as evidence of their role inside the coalition. The marginal effect indicates that a one percentage point increase in the index leads to an increase in the probability to reform by $0.46 \%$ (a one-standard deviation increase in Herfgov increases it by close to 12 percentage points). Likewise, the presence of a strong party in the opposition, identified by the Herfindahl index of the opposition, Herfopp, facilitates the adoption of labor tax reforms, probably for the same reason: the government can then more easily maneuver and tailor its reform to buy out opposition. Conversely, a larger number of opposition parties (i.e. a lower Herfopp) increases the number of veto players. We also control for the size of the majority in terms their share of total parliamentary seats. We find a positive and significant effect for maj at the $10 \%$ level. The marginal effect is substantial, since a one percentage-point increase in the majority increases the probability of reform by $1.08 \%{ }^{18}$

Controlling for the length of the parliamentary term parliamentterm, we find that governments with longer tenure tend to spread their reforms over the term and practice gradualism, but do not reform more overall: increasing tenure from 4 to 5 years reduces the probability of reform in a given year by $26.2 \%$. This is consistent with the idea that longer terms reduce political competition and the need for electorally-motivated reform (see also Schultz 2008). To test for electoral cycle effects, we control for the ratio of the number of years left in the current mandate over the length of the legislative mandate (Parlyterm). We do not find any evidence that governments time their tax reforms with elections (in unreported regressions, we also tested for non-linear effects by introducing a quadratic term, with the same conclusion). ${ }^{19}$ We also introduce a dummy variable indicating whether a member of the ruling coalition has specific political interest (Govspec). It enters with the expected sign but is not significant. Finally, we find that both left- and right-wing governments are less likely - by 24 and $30 \%$ respectively - to reform than a centrist government. This is in line with the theory of Cukierman and Tommasi (1998) which predicts that governments perceived as pro-status-quo are more likely to succeed in reforming because voters see them as more credible when they claim that a reform is necessary. This basic model is already relatively successful in predicting reforms as its forecast is correct in about $69 \%$ of cases.

In regression (2) we add economic variables as controls. A high implicit tax rate on labor in the previous period, lagitrlabor, is an incentive to reform. Indeed, the variable enters positively and significantly at the $10 \%$ level but has little economic significance: increasing the implicit tax rate by

18 To test further the hypothesis of political competition, we ran several additional unreported regressions. Replacing the Herfindahl indexes by a global Herfindahl index for all parties does not affect the results, nor does removing them altogether. We also checked for the effect of the mean district magnitude for the Parliament, a variable taken from the World Bank DPI database that represents the degree of proportionality in the electoral system: this variable takes a negative and significant (at 5\% level) sign, indicating that, ceteris paribus, proportional representation tends to hinder reform, which is consistent with Persson, Roland and Tabellini (1997), Milesi-Ferretti et al. (2002), and Persson and Tabellini (2003). The effect that broader coalitions reform more is thus a feature of the reform tactics chosen by the government, and not of the electoral system itself. In this regression, all the other variables keep their sign but only execoalition maintains its significance.

${ }^{19}$ Unfortunately, our data do not allow us to disentangle international information spillovers from the timing of elections (see section 5). 
one point increases the likelihood of reform by $0.015 \%$. A large size of the public sector - proxied by the compensation of government employees over GDP - is predicted to favor the status quo. This variable enters the regression negatively but is not significant. Finally, economic conditions are reflected by the output gap. Our results run against Alesina and Drazen' (1991) prediction that reforms are more likely when the economy performs less well. To the contrary, at least during the period under consideration, reforms were more likely when economic conditions improved: a one percentage-point increase in the output gap increases the probability of a reform by $10.1 \%{ }^{20}$ Taking the direction of most reforms into account, governments are actually found to engage in pro-cyclical reforms: they reduce taxation when economic conditions improve. The other variables are largely unaffected qualitatively and their marginal effects remain of similar magnitude, despite potential multicollinearity issues.

In regression (3), we substitute demographic controls for economic ones. We find that a onepoint increase in the share of the population over 65 increases the likelihood of reforms by $6.9 \%$. In contrast, population homogeneity is not significant. Note still that collinearity problems imply that some of the core variables cease to be significant. The same problem occurs in regression (4) which controls for labor market indicators. The activity rate of older workers (actrateolder) has the expected sign but is not significant, whereas a larger gender gap in employment rate (emplgendergap) does tend to accelerate reforms. ${ }^{21}$ The strictness of employment protection legislation (epl) has a positive but insignificant sign. ${ }^{22}$ Finally, unionization (uniondensity) has a small positive effect on the occurrence of labor tax reforms, suggesting that stronger unions may facilitate reforms, possibly via the institutionalization of the social dialogue. ${ }^{23}$ Finally, among the political economy variables, only the number of parties in the coalition remains significant. Putting all variables together in regression (5) further aggravates collinearity problems. Finally, we test for lagged effects in regression (6). The variable enters positively but is insignificant in table (3), i.e. when all reforms are considered together. The other results are broadly similar to the ones in regression (1).

${ }^{20}$ To confirm this, we substitute the unemployment rate for the output gap (unreported regression). Its coefficient is negative and significant at $10 \%$, indicating that high unemployment hinders reforms. A one percentage point increase in the unemployment rate decreases the likelihood of tax reform by $2.1 \%$.

${ }^{21}$ We can only identify 4 "Lisbon" reforms that are specifically targeted to women. This prevents us from testing if the effect of the gender employment gap is directly related to gender-specific measures. The effect of the gap on the reforms targeted to low income is not statistically significant.

${ }^{22}$ The interactions between labor tax reforms and labor markets legislation reforms are potentially important, in particular whether they are substitute or complement. To the best of our knowledge, there is no empirical study on this particular issue, and the lack of significance in our regression leaves the question open.

${ }^{23}$ As unreported robustness checks, we used variables on the number of strikes, the number of workers involved in these strikes and the number of days lost in strikes (data from the International Labor Organization), which we divided by the working-age population. These variables are very correlated with each other. Only the relative number of workers involved in strikes turns significant. Its marginal effect is positive. 
Table (4) provides mirror regressions for targeted reforms. ${ }^{24}$ In regression (1), Execoalition, and Herfopp are positive and significant, with marginal effects close to their values in Table (3). Interestingly, the left and right variables cease to be significant (and change sign) in all the regressions of table (4). This may be an indication that targeted reforms need not be associated with a political color but are used by all parties to win the support of specific voter groups, as suggested by Colonel Blotto Games. Regressions (2) to (5) display results that are qualitatively similar to regression (1). Several points are nevertheless worth emphasizing. First, with the exception of a small effect of the output gap, economic variables are no longer significant. This is indication that targeted reforms are politically motivated. Second, the size of the majority seems to play no role. This shows again that, unlike general reforms that necessitate broad political support, targeted reforms might be political acts targeting specific constituencies. This argument is strengthened by the statistically insignificant role of the Herfindahl index of the government in Table (4).

Finally, the lag of the dependent variable is now positive and significant at the $10 \%$ level. The marginal effect indicates that passing a targeted reform in the previous period increases the probability of a targeted reform in the current period by $16.5 \%$. Together with the fact that the effect was not significant in table (3), this is a strong indication that governments do exploit the possibilities offered by gradualism and divide-and-rule tactics (see section 4). Targeting different groups at different times allows them to get around some of the oppositions to reform.

\section{Conclusions}

We have surveyed several political economy theories of tax systems and reforms and identified several testable predictions from these analyses. Among others, we have identified that (a) policymakers may have an incentive to introduce targeted reforms, even when broad reforms may be more efficient, (b) a higher number of political parties in the ruling coalition should increase the number of reforms, (c) reforming is easier with governments that are more pro-status-quo, and (d) reforms should be more likely in periods of economic crisis.

We took these predictions to the data by exploiting the LABREF database of reforms in labor taxation in the European Union between 2000 and 2007. We checked the determinants of all reforms and of targeted reforms. The results fit most of the comparative statics we could test for and provide evidence that political variables carry more weight in triggering reforms than economic explanatory variables. In particular, most reforms are targeted and the number of parties in the coalition is always a better predictor of reforms than either the economic business cycle, the rate of activity in the labor

\footnotetext{
${ }^{24}$ As indicated above, most targeted reforms are of Lisbon type. Regressing only on Lisbon reforms provides similar results (unreported). This suggests that even reforms that aim at increasing efficiency are mainly driven by political economy considerations more than by economic factors.
} 
market, or other socio-economic variables. Also, pro-status-quo governments tend to pass more reforms than a priori pro-reforms governments.

In contrast, reforms are not found to be more likely in periods of economic crisis. To the contrary, we found that governments tended to introduce more tax reforms in good economic times, typically to reduce tax rates or the tax base. However, our analysis focuses on the years prior to the present economic crisis and it may still be true that deep crises produce more, and better, reforms. But we do find evidence of the contrary in less dramatic times.

Future research should extend this analysis and identify how different these patterns are in crisis times in comparison to such a business-as-usual period. This would provide a better understanding of how democratic forces shape the dynamics of tax systems in the longer term. It could also combine the insights provided by our analysis, which identifies the actual decisions made by governments, with the Luxembourg Income Study (LIS) database, to assess the distributive impact of each measure. Finally, the literature does not yet allow us to assess whether each reform is economically meaningful or not, given each institutional and socioeconomic system. A better understanding of the various needs in addition to the diversity of political economy constraints would produce useful policy recommendations. 
Table (3): The impact of political variables on reforms.

\begin{tabular}{|c|c|c|c|c|c|c|}
\hline \multirow[t]{2}{*}{ All Reforms } & (1) & (2) & (3) & (4) & (5) & (6) \\
\hline & Base regression & Econ. Var. & Demographic var. & Labour Market & All variables & Lag depend v \\
\hline \multirow[t]{3}{*}{ execoalition } & $0.450^{\star \star \star}$ & $0.357^{\star *}$ & $0.343^{\star \star}$ & $0.663^{*}$ & $0.804^{\star \star}$ & $0.428^{\star \star \star}$ \\
\hline & $(0.136)$ & $(0.160)$ & (0.149) & $(0.373)$ & $(0.404)$ & $(0.146)$ \\
\hline & [0.111] & {$[0.088]$} & [0.085] & [0.149] & {$[0.178]$} & [0.103] \\
\hline \multirow[t]{3}{*}{ herfgov } & $1.850^{\star \star}$ & $2.314^{\star \star}$ & 0.439 & 1.624 & 1.614 & $1.858^{*}$ \\
\hline & $(0.875)$ & (1.032) & (1.064) & (2.041) & (1.981) & (0.985) \\
\hline & {$[0.457]$} & {$[0.569]$} & {$[0.108]$} & [0.365] & [0.357] & [0.448] \\
\hline \multirow[t]{3}{*}{ herfopp } & $2.050^{* \star}$ & 1.339 & $2.129^{\star \star}$ & 2.601 & 1.036 & $1.741^{*}$ \\
\hline & $(0.959)$ & (1.032) & $(0.944)$ & $(1.817)$ & (1.961) & (1.047) \\
\hline & {$[0.506]$} & [0.330] & {$[0.526]$} & {$[0.584]$} & [0.229] & [0.420] \\
\hline \multirow[t]{3}{*}{ maj } & $4.358^{*}$ & 4.078 & 1.580 & -0.494 & -1.412 & 4.325 \\
\hline & (2.542) & (2.703) & $(2.713)$ & (3.226) & $(4.602)$ & (2.797) \\
\hline & [1.077] & [1.003] & [0.390] & {$[-0.111]$} & {$[-0.312]$} & [1.043] \\
\hline \multirow[t]{3}{*}{ left } & $-0.983^{\star \star}$ & $-0.847^{*}$ & $-1.018^{\star \star}$ & 0.439 & 0.670 & -0.736 \\
\hline & $(0.466)$ & $(0.480)$ & $(0.495)$ & $(0.728)$ & (0.999) & $(0.507)$ \\
\hline & {$[-0.241]$} & {$[-0.208]$} & {$[-0.249]$} & [0.097] & [0.145] & {$[-0.179]$} \\
\hline \multirow[t]{3}{*}{ right } & 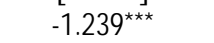 & -0.776 & $-1.349 * \star \star$ & -1.022 & -0.454 & $-1.070^{* \star}$ \\
\hline & $(0.450)$ & $(0.518)$ & $(0.462)$ & $(0.676)$ & $(0.850)$ & $(0.470)$ \\
\hline & {$[-0.300]$} & {$[-0.191]$} & {$[-0.325]$} & {$[-0.235]$} & {$[-0.102]$} & {$[-0.259]$} \\
\hline \multirow[t]{3}{*}{ govspec } & 0.460 & 0.755 & 0.476 & 0.680 & 0.526 & 0.169 \\
\hline & $(0.507)$ & $(0.517)$ & $(0.494)$ & $(0.747)$ & $(0.838)$ & $(0.513)$ \\
\hline & [0.111] & {$[0.176]$} & [0.115] & [0.139] & [0.108] & {$[0.040]$} \\
\hline \multirow[t]{3}{*}{ parlyterm } & -0.328 & -0.094 & -0.321 & -0.042 & 0.024 & -0.187 \\
\hline & $(0.563)$ & $(0.587)$ & $(0.569)$ & $(0.802)$ & $(0.860)$ & $(0.575)$ \\
\hline & {$[-0.081]$} & {$[-0.176]$} & {$[-0.079]$} & {$[0.009]$} & {$[0.005]$} & {$[-0.045]$} \\
\hline \multirow[t]{3}{*}{ parliamentterm } & $-1.223^{\star \star *}$ & $-1.207^{\star *}$ & -0.698 & -0.202 & -0.718 & $-1.104^{\star \star}$ \\
\hline & $(0.450)$ & $(0.488)$ & $(0.492)$ & $(0.906)$ & (1.118) & $(0.461)$ \\
\hline & {$[-0.302]$} & {$[-0.297]$} & {$[-0.173]$} & {$[-0.045]$} & {$[-0.159]$} & {$[-0.266]$} \\
\hline \multirow[t]{3}{*}{ outputgap } & & $0.302^{\star \star *}$ & & & $0.525^{\star \star}$ & \\
\hline & & $(0.101)$ & & & $(0.239)$ & \\
\hline & & {$[0.074]$} & & & {$[0.116]$} & \\
\hline \multirow[t]{3}{*}{ complgovempl } & & -0.091 & & & -0.201 & \\
\hline & & $(0.069)$ & & & $(0.201)$ & \\
\hline & & {$[-0.022]$} & & & {$[-0.045]$} & \\
\hline \multirow[t]{3}{*}{ lagitrlabor } & & $0.060^{*}$ & & & -0.032 & \\
\hline & & $(0.033)$ & & & $(0.078)$ & \\
\hline & & {$[0.015]$} & & & {$[-0.001]$} & \\
\hline \multirow[t]{3}{*}{ pop65 } & & & $0.279^{\star \star \star}$ & & 0.072 & \\
\hline & & & $(0.107)$ & & $(0.239)$ & \\
\hline & & & [0.069] & & {$[0.016]$} & \\
\hline \multirow[t]{3}{*}{ ethnic } & & & 0.846 & & 1.615 & \\
\hline & & & $(1.042)$ & & $(2.507)$ & \\
\hline & & & {$[0.209]$} & & {$[0.357]$} & \\
\hline epl & & & & 0.491 & 0.385 & \\
\hline & & & & $(0.538)$ & $(0.755)$ & \\
\hline & & & & [0.110] & {$[0.085]$} & \\
\hline Emplgendergap & & & & $0.117^{\star \star}$ & 0.065 & \\
\hline & & & & $(0.049)$ & $(0.071)$ & \\
\hline & & & & {$[0.026]$} & {$[0.014]$} & \\
\hline Actrateolder & & & & -0.023 & -0.040 & \\
\hline & & & & $(0.036)$ & $(0.044)$ & \\
\hline & & & & {$[-0.005]$} & {$[-0.009]$} & \\
\hline Uniondensity & & & & $0.038^{\star}$ & 0.037 & \\
\hline & & & & $(0.023)$ & $(0.035)$ & \\
\hline & & & & {$[0.009]$} & {$[0.008]$} & \\
\hline lagreform & & & & & & 0.449 \\
\hline & & & & & & (0.358) \\
\hline & & & & & & [0.108] \\
\hline Observations & 216 & 211 & 216 & 122 & 122 & 189 \\
\hline Pseudo R-squared & 0.15 & 0.19 & 0.17 & 0.21 & 0.24 & 0.13 \\
\hline Goodness of fit & 0.690 & 0.706 & 0.704 & 0.730 & 0.738 & 0.698 \\
\hline
\end{tabular}

Estimation is by logit model. White (1980)'s heteroskedasticity-consistent standard errors are reported between parentheses. Marginal effects are reported between squared brackets. All regressions include unreported time fixed effects and a constant. The goodness of fit is the percentage of correct predictions (either fitted value of reform $>0.5$ and actual reform=1 or fitted value of reform $=<0$ and actual reform $=0) . *$ significant at $10 \% ; * *$ significant at $5 \% ; * * *$ significant at $1 \%$. 
Table (4): The impact of political variables on targeted reforms.

Targeted Reforms

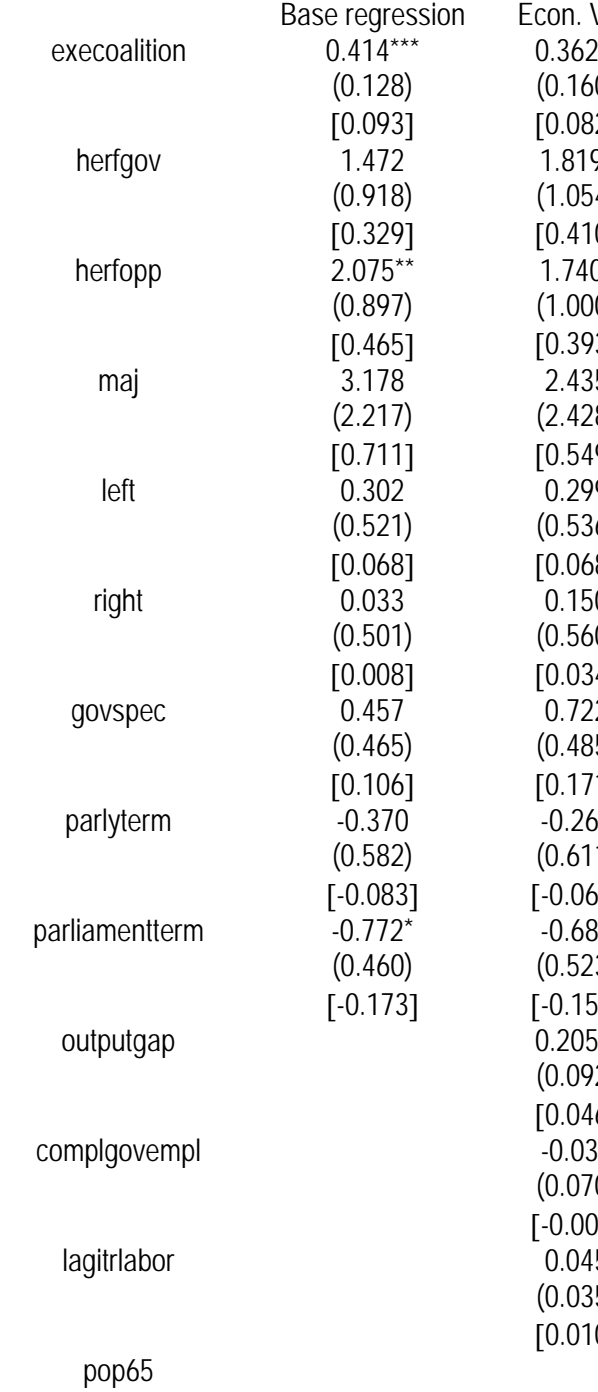

Var. Demographic var.

$0.342^{\star *}$

(0.160)

.082]

(1.054)

$0.410]$

.000)

.393]

2.435

(2.428)

.549]

0.299

$0.068]$

.150

$0.034]$

0.722
$0.485)$

$0.171]$

$0.611)$

$0.061]$

$0.523)$

.154]

$205^{\star \star}$

$0.046]$

0.035

$0.008]$

0.045

$0.010]$

$(0.139)$
$[0.076]$

$0.076]$
0.320

(1.093)

[0.071]

$2.166^{\star *}$

(0.927)

[0.483]

1.507

(2.519)

[0.336]

0.255

(0.541)

[0.057]

$-0.066$

(0.501)

[-0.015]

0.479

(0.474)

$-0.371$

(0.581)

[-0.083]

$-0.502$

(0.495)

[-0.112]

(2)

[0.111]
(4)

Labour Market

$0.442^{*}$

$(0.258)$

[0.110]

1.086

(1.917)

[0.270]

2.768

(1.797)

[0.689]

$-2.481$

(3.054)

[-0.618]

0.595

$(0.718)$

[0.147]

$-0.503$

$(0.675)$

[-0.124]

0.978

$(0.679)$

[0.237]

0.184

$(0.795)$

[0.046]

0.304

(0.890)

[0.076]

\begin{tabular}{|c|c|c|}
\hline & $(0.228)$ & \\
\hline & [0.071] & \\
\hline & -0.083 & \\
\hline & (0.161) & \\
\hline & {$[-0.021]$} & \\
\hline & 0.005 & \\
\hline & $(0.073)$ & \\
\hline & [0.001] & \\
\hline & -0.230 & \\
\hline & $(0.211)$ & \\
\hline & {$[0.057]$} & \\
\hline & -0.068 & \\
\hline & (2.089) & \\
\hline & {$[0.017]$} & \\
\hline 0.522 & 0.988 & \\
\hline (0.491) & $(0.714)$ & \\
\hline$[0.130]$ & [0.245] & \\
\hline $0.071^{*}$ & 0.064 & \\
\hline$(0.040)$ & $(0.061)$ & \\
\hline [0.018] & {$[0.016]$} & \\
\hline 0.003 & -0.014 & \\
\hline (0.033) & $(0.045)$ & \\
\hline$[0.001]$ & {$[-0.003]$} & \\
\hline 0.029 & 0.045 & \\
\hline (0.019) & (0.031) & \\
\hline \multirow[t]{3}{*}[0.007]{} & [0.011] & \\
\hline & & $\begin{array}{c}0.705^{\star} \\
(0363)\end{array}$ \\
\hline & & {$[0.165]$} \\
\hline 122 & 122 & 189 \\
\hline 0.16 & 0.18 & 0.12 \\
\hline 0.705 & 0.705 & 0.667 \\
\hline
\end{tabular}

(5) (6)

All variables

$0.484^{\star *}$

[0.120] [0.083]

$1.914 \quad 1.018$

(2.101) (0.992)

[0.475] [0.234]

$2.0921 .684^{*}$

(1.857) (0.975)

[0.519] [0.388]

$-1.614 \quad 2.315$

(4.399) (2.465)

$[-0.400] \quad[0.533]$

$1.133 \quad 0.620$

(1.118) (0.530)

[0.275] [0.145]

$0.062 \quad 0.087$

$(0.893) \quad(0.513)$

[0.015] [0.020]

$\begin{array}{ll}1.041 & 0.235\end{array}$

$(0.784) \quad(0.494)$

[0.252] [0.055]

$0.293 \quad-0.028$

$(0.837) \quad(0.591)$

[0.073] [-0.018]

$0.161 \quad-0.410$

(1.118) (0.498)

[0.040] [-0.094]

0.286

$(0.228)$

$(0.161)$

$[-0.021]$

0.005

$(0.073)$

$0.001]$

0.705
0.154

(0.109)

[0.034]

1.270

(1.027)

[0.283]

epl

Emplgendergap

Actrateolder

Uniondensity

lagreform

$\begin{array}{cc}\text { Observations } & 216 \\ \text { Pseudo R-squared } & 0.11 \\ \text { Goodness of fit } & 0.685\end{array}$

211
0.13
0.697

216
0.12
0.694

Estimation is by logit model. White (1980)'s heteroskedasticity-consistent standard errors are reported between parentheses. Marginal effects are reported between squared brackets. All regressions include unreported time fixed effects and a constant. The goodness of fit is the percentage of correct predictions (either fitted value of reform $>0.5$ and actual reform=1 or fitted value of reform $=<0$ and actual reform $=0$ ). * significant at $10 \% ; * *$ significant at $5 \% ; * * *$ significant at $1 \%$. 


\section{References.}

Acemoglu, D., Golosov, M. and A. Tsyvinski (2010). "Dynamic Mirrlees Taxation under Political Economy Constraints", The Review of Economic Studies, 77: 841-881.

Acemoglu, D., Golosov, M. and A. Tsyvinski (2011). "Political Economy of Ramsey Taxation", Journal of Public Economics, 95: 467-475.

Alesina, A. (1987). "Macroeconomic policy in a two-party system as a repeated game". Quarterly Journal of Economics 102: 651-678.

Alesina, A. (1988). "Macroeconomics and Politics". In NBER Macroeconomics Annual, Stanley Fischer, (ed.). Cambridge, MA: The MIT Press

Alesina, A. and A. Drazen (1991). "Why are Stabilizations delayed?". American Economic Review, 81(5): 1170-1188.

Bassett, W.F., Burkett, J.P. and L. Putterman (1999). "Income distribution, government transfers, and the problem of unequal influence". European Journal of Political Economy, 15(2): 207-228.

Bénabou, R. (1996). "Inequality and Growth", NBER Macroeconomics Annual, Ben Bernanke and Julio Rotemberg eds. MIT Press, 11-74

Besley, T. and Case, A. (1995a). "Incumbent Behaviour: Vote Seeking, Tax Setting and Yardstick Competition". American Economic Review, 85(1): 25-45.

Besley, T. and Case, A. (1995b). "Does Electoral Accountability Affect Economic Policy Choices? Evidence from Gubernatorial Terms Limits". The Quarterly Journal of Economics, 10(3): 769-798.

Boeri, T., Castanheira, M., Faini, R. and V. Galasso (2006). Structural Reforms Without Prejudice. Oxford University Press.

Borck, R. (2007). "Voting, Inequality and Redistribution". Journal of Economic Surveys, 21(1): 90109.

Bordignon, M., Revelli, F., and Cerniglia, F. (2003). "In search of yardstick competition: A spatial analysis of Italian municipality property tax setting". Journal of Urban Economics, 54: 199-217.

Calvert, R.L. (1985). "Robustness of the Multidimensional Voting Model: Candidate Motivations, Uncertainty, and Convergence". American Journal of Political Science, 29(1): 69-95.

Castanheira, M., Nicodeme, G and P. Profeta (2010). "On the political economics of taxation", in Petretto, A. and Padovano, F. (eds), Public choice and political economy, Franco Angeli editions, 76102.

Castanheira, M., Nicodeme, G and P. Profeta (2011). "On the political economics of tax reforms", CESifo Working Paper, 3538.

Castanheira, M. and C. Valenduc (2006). "Economie Politique de la Taxation". Reflets et Perspectives de la Vie Economique, 45(3): 19-37.

CIA (2007). The World Factbook. https://www.cia.gov/library/publications/the-world-factbook/

Crutzen, B. and N. Sahuguet (2009). "Redistributive Politics with Distortionary Taxation", The Journal of Economic Theory, 144(1): 264-279

Cukierman, A. and M. Tommasi (1998). "When Does It Take a Nixon to Go to China?," American Economic Review, 88(1): 180-97

Davis, O., M. DeGroot, and M. Hinich (1972). "Social preference orderings and majority rule", Econometrica, 40(1): 147-157

De Mooij, R.A. and G. Nicodème (2008). "Corporate Tax Policy and Incorporation in the EU", International Tax and Public Finance, 15: 478-498.

Dewatripont, M. and G. Roland (1992). "Economic Reform and Dynamic Political Constraints". Review of Economic Studies, 59(4): 703-730

Dewatripont, M. and G. Roland (1995). "The Design of Reform Packages under Uncertainty". American Economic Review, 85(5): 1207-1223.

Dixit, A. and J. Londregan (1998). "Fiscal federalism and redistributive politics". Journal of Public Economics, 68(2): 153-180. 
Downs, A. (1957). "An Economic Theory of Political Action in a Democracy". The Journal of Political Economy, 65(2): 135-150.

Drazen, Alan (1996), “The Political Economy of Delayed Reform”, Policy Reform

Edmark, K. and Agren, H. (2007). "Identifying strategic interactions in Swedish local income tax policies". Journal of Urban Economics, 63(3): 849-857.

Esping-Andersen, G. (1990). The Three Worlds of Welfare Capitalism. Oxford: Polity Press.

Feld, L.P. and J. Schnellenbach (2007). "Still a Director's Law? On the Political Economy of Income Redistribution". IREF mimeo

Fernandez, R. and Rodrik, D. (1991), "Resistance to reform: Status quo bias in the presence of individual specific uncertainty", American Economic Review, 81: 1146-1155.

Galli, E. and P. Profeta (2009). "The political economy of tax complexity" Public Finance and Management 9(2).

Gouveia, M and Masia, N.A. (1998). "Does the Median Voter Model Explain the Size of Government? Evidence from the States". Public Choice, 97(1-2): 159-177.

Grossman, G. and E. Helpman (2001). Special interest politics. Cambridge: MIT Press

Hettich, W. and Winer, S.L. (1999). Democratic Choice and Taxation. Cambridge University Press.

Heyndels, B. and Vuchelen, J. (1998). "Tax mimicking among Belgian municipalities". National Tax Journal, 51(1), 89-102.

Keefer, P. (2007). DPI2006: Database of Political Institutions. World Bank.

Laver, M, and K. Shepsle (1996). Making and Breaking Governments, Cambridge: Cambridge University Press.

Le Grand, J. (1982). The strategy of equality: redistribution and the social services. Allen \& Unwin, London.

Lindbeck, A. and W.W. Weibull (1987). "Balanced-budget redistribution as the outcome of political competition". Public Choice, 52: 273-297.

Lizzeri, A. and N. Persico (2001). "The Provision of Public Goods under Alternative Electoral Incentives". The American Economic Review, 91(1): 225-239.

Lizzeri, A. and N. Persico (2005). "A Drawback of Electoral Competition". The Journal of the European Economic Association, 3(6): 1318-1348.

Long, and J. Freese (2006). Regression Models of Categorical Dependent Variables using Stata. Stata Press Publication.

Martinelli, C. and M. Tommasi (1997). "Sequencing of economic reforms in the presence of political constraints", Economics and Politics, 9(2): 115-131.

Metzler, A. and S. Richard (1981). "A Rational Theory of the Size of Government". Journal of Political Economy. 89 (5): 914-927.

Metzler, A. and S. Richard (1983). "Tests of a rational theory of the size of government". Public Choice, 41: 403-418.

Milanovic, B. (2000). "The median-voter hypothesis, income inequality, and income redistribution: an empirical test with the required data". European Journal of Political Economy, 16(3): 367-410.

Milesi-Ferretti, G.M., R. Perotti and M. Rostagno (2002). "Electoral Systems and Public Spending." Quarterly Journal of Economics, 117: 609-657

Mueller, D.C. (2003). Public Choice III. Cambridge University Press.

Myerson R.B. (1993), "Incentives to cultivate favored minorities under alternative electoral systems". American Political Science Review 87: 856-869.

Nordhaus, W. (1975). “The political business cycle”. Review of Economic Studies 42:169-190.

Perotti, R. (1993). "Political Equilibrium, Income Distribution, and Growth". Review of Economic Studies, 60(4): 755-76.

Perotti, R. (1996). "Growth, Income Distribution, and Democracy: What the Data Say". Journal of Economic Growth, 1(2): 149-187. 
Persson, T., G. Roland and G. Tabellini (1997). "Separation of Powers and Political Accountability," The Quarterly Journal of Economics, 112(4): 1163-1202.

Persson, T. and G. Tabellini (2000). Political Economics: Explaining Economic Policy. MIT Press.

Persson, T. and G. Tabellini (2003). The Economic Effects of Constitutions. MIT Press

Profeta, P. (2007). "Political Support and tax reforms with an application to Italy", Public Choice 131: $141-55$

Profeta, P. (2008). "Income tax reforms in Italy" CESifo Dice Report, Spring 2008.

Ramsey, F.P. (1927). "A Contribution to the Theory of Taxation". The Economic Journal, 37: 47-61.

Revelli, F. (2002). "Local taxes, national politics and spatial interactions in English district election results." European Journal of Political Economy, 18: 281-299.

Roberts, K.W.S. (1977). "Voting over income tax schedules". Journal of Public Economics, 8(3), pp. 329-340.

Rodrik, D. (1996). "Understanding Economic Policy Reform," Journal of Economic Literature, 24, pp. 9-41.

Rogoff, K., and A. Sibert (1988). "Elections and macroeconomic policy cycles". Review of Economic Studies 55:1-16.

Roland, G. (2000). Transition and Economics. MIT Press.

Roemer, J.E. (2001). Political Competition. Harvard University Press.

Romer, T. (1975). "Individual welfare, majority voting, and the properties of a linear income tax". Journal of Public Economics, 4(2): 163-185.

Scheve, K. and D. Stasavage (2010), "The Conscription of Wealth: Mass Warfare and the Demand for Progressive Taxation", International Organization, 64: 529-561.

Schofield, N. (1983). "Generic Instability of Majority Rule”, Review of Economic Studies, 50(4): 695705.

Schultz, C. (2008). "Information, polarization and term length in democracy". Journal of Public Economics, 92(5-6): 1078-1091

Stigler, G.J. (1970). "The Director's Law of Public Income Redistribution". The Journal of Law and Economics. 13(1): 1-10.

Tullock, G. (1983). Economics of Income Redistribution. Kluwer.

Valenduc, C. (2006). "Une flat tax en Belgique ? Quelques éclairages sur les principes et les conséquences d'une telle réforme". Reflets et Perspectives de la Vie Economique, 45(3): :19-37.

Warskett, G. Winer, S. and W. Hettich (1998). "The complexity of the tax structure in competitive political systems", International Tax and Public Finance, 5: 123-151.

Winer, S. (2001), "Normative Public Finance for Political Economists", Handbook of Public Finance.

Wittman, D. (1983). "Candidate Motivation: A Synthesis of Alternative Theories". The American Political Science Review, 77(1): 142-157. 
Appendix A. Variable definitions and data sources

\begin{tabular}{|c|c|c|}
\hline Variable & Definition & Source \\
\hline Reform & $\begin{array}{l}\text { Dummy indicating the occurrence of a reform in labour } \\
\text { taxation }\end{array}$ & $\begin{array}{l}\text { LABREF (European Commission) } \\
\text { and own calculations }\end{array}$ \\
\hline Targeted & $\begin{array}{l}\text { Dummy indicating the occurrence of a targeted reform } \\
\text { in labour taxation }\end{array}$ & $\begin{array}{l}\text { LABREF (European Commission) } \\
\text { and own calculations }\end{array}$ \\
\hline Execoalition & Number of parties in the governing coalition & $\begin{array}{l}\text { CIA Factbooks and own } \\
\text { calculations }\end{array}$ \\
\hline Herfgov & $\begin{array}{l}\text { Herfindahl index for the governing coalition (in \% of } \\
\text { seats) }\end{array}$ & DPI (World Bank) \\
\hline Herfopp & Herfindahl index for the opposition (in \% of seats) & DPI (World Bank) \\
\hline Maj & Percentage of majority in seats & DPI (World Bank) \\
\hline Right & Dummy indicating a right-wing government & DPI (World Bank) \\
\hline Left & Dummy indicating a left-wing government & DPI (World Bank) \\
\hline Parliamentterm & Length in years of the parliamentary term & DPI (World Bank) \\
\hline Parlyterm & $\begin{array}{l}\text { Number of years left in the current term divided by the } \\
\text { length of the term }\end{array}$ & $\begin{array}{l}\text { DPI (World Bank) and own } \\
\text { calculations }\end{array}$ \\
\hline Govspec & $\begin{array}{l}\text { dummy variable indicating whether a member of the } \\
\text { ruling coalition has specific political (nationalist, } \\
\text { regional, religious or rural) interest }\end{array}$ & DPI (World Bank) \\
\hline Pop65 & Share of the total population aged 65 or more & CIA Factbooks \\
\hline Ethnic & Herfindahl index of the various ethnic & $\begin{array}{l}\text { CIA Factbooks and own } \\
\text { calculations }\end{array}$ \\
\hline Outputgap & $\begin{array}{l}\text { Output gap of the economy (a positive index indicates } \\
\text { GDP above potential GDP) }\end{array}$ & AMECO (European Commission) \\
\hline Complgovempl & Compensation of employees of government in \% GDP & $\begin{array}{l}\text { AMECO (European Commission) } \\
\text { and own calculations }\end{array}$ \\
\hline Unemplr & Unemployment rate & $\begin{array}{l}\text { AMECO (European Commission) } \\
\text { and own calculations }\end{array}$ \\
\hline Lagitrlabor & $\begin{array}{l}\text { Lag of the Implicit tax rate on labour (computed as } \\
\text { labour taxes collected on their own base) }\end{array}$ & $\begin{array}{l}\text { Taxation Trends (European } \\
\text { Commission) }\end{array}$ \\
\hline EPL & $\begin{array}{l}\text { Strictness of Employment Protection Legislation. The } \\
\text { indicator varies between } 1 \text { (less strict) and } 6 \text { (stricter). } \\
\text { The OECD indicators of employment protection } \\
\text { measure the procedures and costs involved in } \\
\text { dismissing individuals or groups of workers and the } \\
\text { procedures involved in hiring workers on fixed-term or } \\
\text { temporary work agency contracts }\end{array}$ & OECD \\
\hline Emplgendergap & $\begin{array}{l}\text { Difference in employment rates between men and } \\
\text { women in percentage points }\end{array}$ & LIME (European Commission) \\
\hline Actrateolder & $\begin{array}{l}\text { Share of employed and unemployed in age groups } 15- \\
64 \text {, as a proportion of total population in the same age } \\
\text { group }\end{array}$ & LIME (European Commission) \\
\hline Uniondensity & $\begin{array}{l}\text { Ratio of wage and salary earners that are trade union } \\
\text { members, divided by the total number of wage and } \\
\text { salary earners. }\end{array}$ & OECD Labour Force Statistics \\
\hline
\end{tabular}

